Columbia Law School

Scholarship Archive

\title{
This Will Hurt Me More Than It Hurts You: Social and Legal Consequences of Criminalizing Delinquency
}

Jeffrey Fagan

Columbia Law School, jfagan@law.columbia.edu

Follow this and additional works at: https://scholarship.law.columbia.edu/faculty_scholarship

Part of the Criminal Law Commons, Criminal Procedure Commons, and the Juvenile Law Commons

\section{Recommended Citation}

Jeffrey Fagan, This Will Hurt Me More Than It Hurts You: Social and Legal Consequences of Criminalizing Delinquency, 16 Notre Dame J. L. Ethics \& PuB. PoL'Y 1 (2002).

Available at: https://scholarship.law.columbia.edu/faculty_scholarship/1267

This Article is brought to you for free and open access by the Faculty Publications at Scholarship Archive. It has been accepted for inclusion in Faculty Scholarship by an authorized administrator of Scholarship Archive. For more information, please contact scholarshiparchive@law.columbia.edu, rwitt@law.columbia.edu. 


\title{
THIS WILL HURT ME MORE THAN IT HURTS YOU: SOCIAL AND LEGAL CONSEQUENCES OF CRIMINALIZING DELINQUENCY ${ }^{\dagger}$
}

\author{
JEFFREY FAGAN*
}

In December, 1998, the European Commission of Human Rights declared Great Britain guilty of three violations of the European Convention on Human Rights in the trial and sentencing of Robert Thompson and Jon Venables in the murder of the toddler Jamie Bulger. ${ }^{1}$ The case was notorious in Britain, the United States, and many other western countries due to the young age of the defendants (both were ten years of age) and the extreme cruelty of their act relative to their young age. The defendants were tried and convicted in a lengthy proceeding in the adult court. The trial judge and Lord Chief Justice recommended eight and ten-year sentences. ${ }^{2}$ The then-British Home Secretary raised the sentences on the two defendants to fifteen years, but this decision was quashed by the House of Lords as procedurally unfair. ${ }^{3}$

This case opened a contentious debate in Great Britain on the age threshold of criminal responsibility for young defendants

Support for this research was provided in part by grants from the MacArthur Foundation Research Program on Adolescent Development and Juvenile Justice, the Annie E. Casey Foundation, and the Open Society Institute. Opinions and mistakes are mine alone. Thanks to Nisha Menon and Carrie Gustafson for excellent research assistance, and to Gillian Metzger for generously sharing her knowledge of statutes.

* Professor of Law, Columbia Law School; Professor of Public Health, Mailman School of Public Health, Columbia University. (2000).

1. V. v. United Kingdom, 30 Eur. Ct. H.R. 121 (ser. C) at 87-120, 130-45

2. R. v. Sec'y of State for the Home Dep't, Ex parte Venables, [1997] 1 All E.R. 327, 343 (H.L. 1997) (appeal taken from Q.B.).

3. Id. at 345. The House of Lords ruled that, in fixing the tariff or minimum period of detention, the Secretary of State had departed from requisite standards of fairness by not making full disclosure of the material facts, by failing to take into account all relevant considerations, and by taking into account irrelevant material derived from the media and public petitions. Id. at 328 . 
and on the allocation of adult punishment for adolescent offenders. ${ }^{4}$ However, the Commission chose to address neither of those concerns. The Commission's opinion narrowly addressed procedural deficiencies involving the trial competence of the very young defendants and due process concerns in the government's attempts to lengthen their sentences. The Commission found that the criminal procedures adopted prevented the boys from participating effectively in their trial, thereby impairing fact-finding and the allocation of responsibility. ${ }^{5}$ It upheld by eighteen to one a further complaint that the way in which the boys' sentences were altered by the then-Home Secretary Michael Howard represented a breach of their human rights, as this decision was taken by a politician and not "an independent and impartial tribunal." 6 The Human Rights Commission decided, again by eighteen to one, that there had been a violation of the boys' right to a review of the lawfulness of the continuation of their imprisonment. ${ }^{7}$

Nevertheless, the Commission's ruling brought the growing American trend to criminalize juvenile delinquency into the international forum of human rights. The Commission relied on specific elements in the United Nations Convention on the Rights of the Child, ${ }^{8}$ including: the right to privacy at all stages of judicial proceedings; ${ }^{9}$ the establishment of a minimum age below which children shall be presumed not to have the capacity to infringe the penal laws; ${ }^{10}$ alternatives to (adult) judicial proceed-

4. See generally Barry Feld, Bad Kids (1999); Franklin E. Zimring, American Youth Violence (1998); The Changing Borders of Juvenile Justice: Transfer of Adolescents to the Criminal Court (Jeffrey Fagan \& Franklin E. Zimring eds., 2000); Christian Pfeiffer, Juvenile Crime and Violence in Europe, 23 CRIme \& Just. 255 (1998); Michael Freeman, The James Bulger Tragedy: Childish Innocence and the Construction of Guilt, in THE Moral STATUS OF ChILdRen 255-303 (1997); Stephanie J. Millet, Note, The Age of Criminal Responsibility in an Era of Violence: Has Great Britain Set a New International Standard? 28 VAND. J. Transnat'L L. 295 (1995); J. Neville Turner, The James Bulger Case: A Challenge to Juvenile Justice Theories, 68 LAw INST. J. 734, 736-37 (1994).

5. See V. v. United Kingdom, 30 Eur. Ct. H.R. 121 (ser. C) at 130-45, 156.

6. Id. at 128.

7. Id. at 164 .

8. U.N. Convention on the Rights of the Child, 28 I.L.M. 1448 (1989) [hereinafter Convention].

9. Id. at art. 40(2) (b) (vii) ("Every child alleged as or accused of having infringed the penal law has at least the following guarantees ... (vii) To have his or her privacy fully respected at all stages of the proceedings.").

10. Id. at art. 40(3) (a).

States Parties shall seek to promote the establishment of laws, procedures, authorities and institutions specifically applicable to children alleged as, accused of, or recognized as having infringed the penal law, and, in particular: (a) The establishment of a minimum age below 
ings, providing that human rights are fully respected; ${ }^{11}$ and fixing the age of criminal responsibility for juveniles at an age level that takes into account the expected emotional, mental and intellectual maturity of children. ${ }^{12}$ Article 40 of the Convention harmonizes two principles that have paralyzed U.S. conceptions of juvenile justice: the need to treat children differently because of their age and level of development and the need to accord children procedural safeguards enjoyed by adults. ${ }^{13}$

In addition, other Convention provisions address the administration of the criminal justice system as it applies to minors, prohibiting "cruel, inhuman or degrading treatment or punishment,"14 obligating signers to provide rehabilitative care, ${ }^{15}$ and declaring that children who have violated (adult) penal laws should be "treated in a manner consistent with the promotion [of the] child's sense of dignity and worth, which reinforces the

which children shall be presumed not to have the capacity to infringe the penal law.

Id.

11. Id. at art. $40(3)$ (b).

States Parties shall seek to promote the establishment of laws, procedures, authorities and institutions specifically applicable to children alleged as, accused of, or recognized as having infringed the penal law, and, in particular: . . (b) Whenever appropriate and desirable, measures for dealing with such children without resorting to judicial proceedings, providing that human rights and legal safeguards are Id. fully respected.

12. Id. at art. 391 .

States Parties shall take all appropriate measures to promote physical and psychological recovery and social reintegration of a child victim of any form of neglect, exploitation, or abuse; torture or any other form of cruel, inhuman or degrading treatment or punishment; or armed conflicts. Such recovery and reintegration shall take place in an environment which fosters the health, self-respect and dignity of the child.

Id.; See also id. at Preamble, which states, "[T] he child, by reason of his physical and mental immaturity, needs special safeguards and care, including appropriate legal protection."

13. Michelle India Baird \& Mina B. Samuels, Youth, Family and the Law: Defining Rights and Establishing Recognition, 5 J.L. \& PoL'y 177, 189 (1996).

14. Convention, supra note 8 , at art. 37(a) ("States Parties shall ensure that: (a) No child shall be subjected to torture or other cruel, inhuman or degrading treatment or punishment.").

15. Id. at art. $40(4)$.

A variety of dispositions, such as care, guidance and supervision orders; counseling; probation; foster care; education and vocational training programmes and other alternatives to institutional care shall be available to ensure that children are dealt with in a manner appropriate to their well-being and proportionate both to their circumId. stances and the offence. 
child's respect for the human rights and fundamental freedoms of others, and which takes into account the child's age and the desirability of promoting the reintegration and the child's assuming a constructive role in society." 16 States Parties are to provide children in institutions with education and vocational training, ${ }^{17}$ recreation and physical training, ${ }^{18}$ and a right of "periodic review of the treatment provided to the child and all other circumstances relevant to his or her placement." 19

Also, the Convention obliges States Parties to take appropriate legislative, administrative, social and educational measures "to protect children from the illicit use of narcotic drugs and psychotropic substances," 20 and "to protect the child from all forms of physical or mental violence, injury or abuse, neglect or negligent treatment, maltreatment or exploitation, including sexual abuse." ${ }^{11}$ Protective measures to be taken by States include "effective procedures for the establishment of social programmes to provide necessary support for the child and for those who have the care of the child, as well as for other forms of prevention and for identification, reporting, investigation, treatment and follow-up of instances of child maltreatment ... and, as appropriate, for judicial involvement."22

In addition to the Convention, at least four other international documents address the circumstances and conditions in which children deprived of liberty must be held. The International Covenant on Civil and Political Rights, a treaty to which the United States is a party, provides that "the essential aim" of prison shall be "reformation and social rehabilitation," and directs States Parties to separate accused juvenile offenders from adults, and to accord juvenile offenders treatment appropriate to their age. ${ }^{23}$ The disparate impact of juvenile transfer on minor-

16. Id. at art. $40(1)$.

17. Id. at art. 28(1) (b) ("States Parties recognize the right of the child to education .... [and] they shall ... (b) Encourage the development of different forms of secondary education, including general and vocational education, [and] make them available and accessible to every child.").

18. Id. at art. 31(1) ("States Parties recognize the right of the child to rest and leisure, to engage in play and recreational activities.").

19. Id. at art. 25.

20. Convention, supra note 8 , at art. 33 .

21. Id. at art. 19(1). See also id. at art. 34 ("States Parties undertake to protect the child from all forms of sexual exploitation and sexual abuse.").

22. Id. at art. 19(2).

23. International Covenant on Civil and Political Rights, opened for signature Dec. 19, 1966, arts. 10(2)(b), 10(3), 14(4), 999 U.N.T.S. 171 [hereinafter $I C C P R]$; see also U.N. Guidelines for the Prevention of Juvenile Delinquency, U.N. GAOR, 45th Sess., Supp. No. 49, U.N. Doc. No. A/RES/45/112 (1990); U.N. Rules for the Protection of Juveniles Deprived of Their Liberty, U.N. 
ity youths also raises implications for the Covenant on the Elimination of All Forms of Racial Discrimination, another treaty to which the United States is a party. ${ }^{24}$

Although the United States has endorsed the Convention, it continues to employ a punitive approach to juvenile justice. ${ }^{25}$ Several reasons account for the United States' failure to take the international standards seriously. ${ }^{26}$ First, it is not uncommon for countries that have ratified major children's rights treaties to also ignore their obligations. ${ }^{27}$ Article Four provides an example of the qualified nature of the obligations assumed by States Parties to the Convention. By attaching the term "appropriate" to the measures a State is to undertake, the drafters provided a convenient rationale for any State inclined to ignore or give pro forma effect to its provisions. Like most human rights texts, the Convention is riddled with qualifying language and subjective terms

GAOR, 45th Sess., Supp. No. 49, U.N. Doc. No. A/RES/45/113 (1990); U.N. Standard Minimum Rules for the Administration of Juvenile Justice, U.N. GAOR, 40th Sess., Supp. No. 53, U.N. Doc. No. A/RES/40/33 (1985). These rules are not widely known or applied in the United States. David P. Stewart, Ratification of the Convention on the Rights of the Child, 5 Geo. J. Fighting PoverTy 161,184 n.182 (1998).

24. International Covenant on the Elimination of All Forms of Racial Discrimination, opened for signature Mar. 7, 1966, 660 U.N.T.S. 195.

25. The United States signed the Convention on February 16, 1995; but remains one of only two countries in the world that has not ratified the Convention. Catherine Langevin-Falcon, Second Class Citizens?, 58(6) Humanisr, Nov. 1, 199. Today, ratification looks even more unlikely than it did four years ago, in part because of the trend at the federal level to treat juveniles as adults.

26. Despite federal activism in juvenile justice, forcing these standards on the states, to the extent that they exceed constitutional requirements, would raise serious federalism issues. David P. Stewart, Ratification of the Convention on the Rights of the Child, 5 Geo. J. Fighting PoverTy 161, 176-78 (1998); see also Lawrence L. Stentzel, Federal-State Implications of the Convention in CHILDREN's Rights in America: U.N. Convention on the Rights of THE Child Compared with United States Law 57-83 (Cynthia Price Cohen \& Howard Davidson eds., 1991).

27. Globalization of Child Law: The Role of the Hague Conventions 41 (Sharon Detrick \& Paul Vlaardingerbroek eds., 1999) ("[The Convention] seeks States Parties without regard to whether they will immediately honor its substantive requirements."); Michael Freeman, Introduction, CHILDREN's RighTs: A Comparative Perspective 4 (Michael Freeman ed., 1996) ("In all the countries surveyed, there is divergence between the new international norms and the law and practice of the countries .... Too many states ratified the Convention ... without giving serious thought to their own laws and practices."); David A. Bolton, The Convention on the Rights of the Child: Prospects for International Enforcement, 12(1) HuM. RTs. Q. 129 (1990) ("[A] sober assessment of the human rights situation throughout the world would reveal the ritual failure of states parties to comply with standards established in instruments such as the Convention."). 
that can be interpreted and applied in whatever manner a State Party chooses. Second, many nations nullify international treaties and agreements by narrowly interpreting their obligations and rights. ${ }^{28}$

Third, the Gault ${ }^{29}$ and Kent $^{30}$ decisions have more positively affirmed procedural rights for juveniles in the United States, while other nations place greater emphasis on the unique interests and capacities of juveniles. ${ }^{31}$ The Gault reforms arose precisely because of the tension between due process rights and the primacy of the child's best interests in the juvenile justice system. Fourth, juvenile crime is an area historically regulated by states. And although Congress has the power to enact legislation to implement the Convention, it has proven unwilling to use its treaty power to infringe state sovereignty. ${ }^{32}$ Finally, reversing the current trend toward punitive measures is difficult because law and policy continue to be shaped by political crises resulting from extreme but rare cases involving juveniles. ${ }^{33}$

28. A. Glenn Mower, Jr., The Convention on the Rights of the Child: INTERNATIONAL SUPPORT FOR CHILDREN 25 (1997).

29. In re Gault, 387 U.S. 1 (1967) (holding that a minor before a juvenile court accused of behavior that may result in confinement has the constitutional right to confront and cross-examine witnesses and to be notified of charges, represented by counsel, and protected against self-incrimination).

30. Kent v. United States, 383 U.S. 541, 560-61 (1966) (holding that an alleged juvenile offender has the right to due process protection from judicial transfer to criminal court without a hearing, without effective assistance of counsel, and without a statement of reasons).

31. Of course, the argument could be made that it is only by providing adequate due process rights that successful reintegration can be achieved. See Jeffrey Fagan, Social and Legal Policy Dimensions of Violent Juvenile Crime, 17 CRIM. Just \& BEHAV. 93, 103 (1990) (noting that the primary rationale for increasingly punitive programs in the juvenile justice system is actually to increase the successful "reintegration of violent delinquents into the community"). See also Trevor Jones et al., Democracy and Policing (1994); David J. Smith, Youth Crime and Conduct Disorders: Trends, Patterns and Causal Explanations, in PsychoSocial. Disorders in Young People 389 (Michael Rutter \& David J. Smith eds., 1995); David J. Smith, Case Construction and the Goals of Criminal Process, 37 BRIT. J. Criminology 319 (1997). See also Desmond Browne, The Criminal Justice System, in Children's Rights in Scotland: Scots Law Analyzed in Light of the U.N. Convention on the Rights of the Child 227-40 (Alison Cleland \& Elaine Sutherland eds., 1996).

32. Kerri Ann Law, Hope for the Future: Overcoming Jurisdictional Concerns to Achieve United States Ratification of the Convention on the Rights of the Child, 62 FORDHAM L. Rev. 1851, 1870 (1994).

33. See, e.g., Franklin E. Zimring, American Youth VIOLEnce (1999) (showing the political tension between the small number of juvenile homicides and the overwhelmingly trivial nature of most youth crime); Katherine BECK. ett, Making Crime Pay: Law and Order in Contemporary Politics (1997) 
The trend in the U.S. toward a more punitive jurisprudence of youth crime places the federal law and laws of most states in direct conflict with many of the human rights concerns expressed in the Convention. ${ }^{34}$ Legislatures across the nation are currently debating a variety of laws and policies to "criminalize" delinquency, and this issue is revisited annually by Congress in legislation designed to "get tough" on youth crime. This past year, Congress has also passed legislation designed to criminalize delinquency, and has provided funds to facilitate state efforts to do the same. ${ }^{35}$ The primary focus of these laws is the removal of adolescent offenders from the juvenile justice system to the criminal courts for sentencing. In addition, several states have expanded the use of adult punishment for adolescent offenders, including incarceration in state prisons. Since 1990, nearly every state and the federal system have expanded the use of adult adjudication and punishment for adolescent offenders. ${ }^{36}$

What happens to adolescents once placed in the criminal justice system and the potential violations of human rights that ensue is the focus of this essay. The pace of change, the severity of the new laws, the potential for unintended negative outcomes, and the empirical reality of adult punishment of juvenile offenders creates new urgency to these questions. Unfortunately, there has been little analysis of the comparative effects of statutes and administrative laws that relocate juvenile offenders to the adult court, and there has been virtually no research on the efficacy,

(illustrating the consolidation of power and resources when legal institutions distort the small number of egregious crimes).

34. See Human Rights Watch, High Country Lockup: Children in Confinement in Colorado (1997); Human Rights Watch, United States Chil DREN IN CONFINEMENT IN Louisiana (1995); Law, supra note 32, at 1854-57; Lauren B. Kallins, The Juvenile Death Penalty: Is the United States in Contravention of Intermational Law?, 17 MD. J. INT'L L. \& TRADE 77 (1993).

35. Both political parties introduced nearly identical legislation in the 106th Congress that would broaden the categories of juvenile offenses and offenders eligible for transfer to the criminal court. In S. 254, 106th Cong. $\S 1302(2000)$ "Certain Punishment and Graduated Sanctions for Youth Offenders" calls for "graduated sanctions" that would require adult punishment after three successive juvenile crimes. This is akin to a "three strikes" law where transfer occurs after a juvenile reaches a threshold of prior offenses and offense severity. The bill provides fiscal incentives to the states, via block grants, to implement these provisions. Similar to S. 10 in the 105th Congress, S. 254 would also eliminate many of the current protections for separating minors from adults in jails and prisons housing adult inmates.

36. See generally Barry C. Feld, BAD Kuds (1999); Franklin E. Zimring, american Youth Violence (1998); The Changing Borders of Juvenile Jus. tice: Transfer of Adolescents to the Criminal Court (Jeffrey Fagan \& Franklin E. Zimring eds., 2000). 
impact and consequences of sentencing juveniles as adults. There also has not been a careful examination of the costs and benefits of "get tough" policies, in particular the mechanisms underlying the unintended consequences of "getting tough" on adolescents. Finally, there have been no efforts to reconcile the theoretical dimensions of the legal threshold of adolescence with theory and research on adolescent development and the natural history of adolescent criminality.

These issues are the focus of the four sections of this article. The first part discusses the tension between competing theoretical dimensions of the jurisprudence of adolescent crime in the context of the current mobilization to shift the threshold of criminal liability downward in age. Although waiver of juveniles to criminal court may signal the "end of childhood" for that offender, ${ }^{37}$ theory and research on adolescent development suggest that the developmental process is far from complete with respect not only to antisocial behavior, but more generalized transitions from adolescence to adult social roles and behaviors. In the second section, I assess the returns to crime control and to retributive justice in current efforts to increase punishment for adolescent offenders and to reduce crime. I review research comparing the punishment and recidivism rates of adolescent offenders adjudicated in juvenile versus adult court, research that includes studies with a variety of sampling and measurement conditions. The results suggest that the policy goal of increasing punishment for adolescent offenders through transfer to the adult courts has generally been achieved. However, utilitarian goals for reducing juvenile crime rates have not been achieved. Evidence has accumulated that increasing the certainty and severity of punishment for adolescents may in fact increase crime rates and heighten the same public safety risks that the legislation is intended to reduce. In the third section, these empirical results are contextualized in theories of adolescent development and criminology to locate the tension of iatrogenic effects with prevailing policies of retribution and deterrence. The fourth section discusses the implications of this theoretical tension for the jurisprudence of adolescent criminality, and for legal and social policy of the American trend to punish juvenile offenders as adults that will shape the theory and future of the juvenile court. This conclusion revisits the human rights dimensions

37. John Conrad, Crime and the Child, in MAJOR Issues IN JUVENILE JUSTICE Information and Training: Readings in Public Policy 179 (J.C. Hall et al. eds., 1981). 


\section{Legal and Developmental Thresholds of Adolescence}

\section{A. Theorizing Transfer Law and Jurispmudence}

The new waiver laws were designed to expand the number and kind of cases where transfer occurs, but this expansive objective was pursued using a wide variety of tactics. The various designs of the transfer "safety valve" will have very different impacts on both juvenile and criminal justice systems. ${ }^{38}$ For example, should transfer standards be designed to facilitate a small number of cases-twenty to one hundred in a state system per year-or to produce two to three thousand? Both types of systems have been constructed. Should decisions be made principally on the juvenile's current charge or his prior record? Should general standards for transfer be made be made in legislation or should discretion be delegated to judges or prosecutors to decide? If discretion becomes the key to transfer decisions, who should be trusted with the power to decide? And on what basis? These are questions with constitutional, theoretical, and practical implications. They address issues as profound as the separation of powers on the one hand and theories of adolescent development on the other.

The principles that govern transfer out of juvenile court are one defining element of a theory of juvenile justice. One cannot know why juvenile court is the appropriate place for the hundreds of thousands of accused delinquents that the court sees without knowing what sorts of otherwise eligible cases are transferred out of the court's jurisdiction and why.

\section{Theories of Adolescence and Theories of Juvenile Justice}

Are the youngsters transferred to criminal courts no longer children in the eyes of the law as a result of that decision ${ }^{39}$ If so, why? If not, how should the continuity of childhood status be acknowledged in the criminal court? And should childhood status be decided on theoretical bases separate from culpability for criminal behavior? These turn out to be important questions about the boundaries of American adolescence. A juvenile court for the adjudication of delinquency has become a standard feature of the legal construction of the first half of adolescence all over the developed world. The exceptions to that practice should not only help us to discern the prevailing theories of juve-

38. Jeffrey Fagan \& Franklin E. Zimring, Editors' Introduction, in THE Changing Borders of Juvenile Justice: Transfer of Adolescents to THE Criminal Court (Jeffrey Fagan \& Franklin E. Zimring eds., 2000).

39. See, e.g., Conrad, supra note 37 , at 179. 
nile justice but also theories of adolescence that form its larger context.

Humans are unique among primates in the extent of their dependence on an extended period of socialization and learning in order to acquire the competencies and capacities of adulthood. ${ }^{40}$ The law has always provided special protections, or exemptions from punishment liability, for young persons who have not achieved those plateaus of adulthood. ${ }^{41}$ After a period of flux, the common law settled on the chronological age of twenty-one to define the status of juvenile, without regard to individual characteristics such as physical maturity, education, experience, or developmental competencies for reasoning or comprehension. ${ }^{42}$ The criminal law generally regarded a lower age of fourteen as the chronological threshold at which offenders were responsible for their actions. ${ }^{43}$

Although states have legislated lower ages in recent years, the anomaly remains that a youth of fifteen cannot enter into a contract but is liable for punishment as an adult for violating the criminal law. The rule of different statutes for different contexts remains the norm. Being of legal age for responsibilities such as criminal punishment does not necessarily guarantee privileges or rights such as drinking, marriage, or operating a motor vehicle. ${ }^{44}$ Some of these anomalies, such as permitting driving before age 18 but restricting drinking until age twenty-one, express the intent to grant privileges to young people while retaining residual control over their abuse of privileges that may endanger the larger populace. ${ }^{45}$

40. D. Richards, The Individual, the Family and the Constitution: A Jurisprudential Perspective, 55 N.Y.U. L. Rev. 1, 20 (1980).

41. Elizabeth Scott et al., Evaluating Adolescent Decision Making in Legal Contexts, 19 Law \& Hum. Behav. 221 (1995); Elizabeth Scott \& Thomas Grisso, The Evolution of Adolescence: A Developmental Perspective on Juvenile Justice Reform, 88 J. Crim. L. \& Criminology 137 (1997). Under the common law, the age of majority was the age at which men were thought strong enough to bear heavy medieval armor. See B. Hafen, Children's Liberation and the New Egalitarianism: Some Reservations about Abandoning Youth to their "Rights, "1976 B.Y.U. L. REV. 605, 613 (1976).

42. Martin R. Gardner, Understanding Juvenile LaW 4 (1997).

43. Frank Ludwig, Rationale of Responsibility for Young Offenders, 29 NeB. L. REv. 521, 527-28 (1950).

44. Robert Mnookin \& D. Kelly Weisberc, Child Family and the State 967 (3d ed. 1995).

45. Franklin E. Zimring, The Changing legal World of Adolescence 26 (1982). 


\section{Amenability as a Socially Constructed Narrative}

These new laws distort the one theoretical construct that historically served as the marker of the boundary: "amenability to treatment." Historically, the sole basis for juvenile court intervention was to correct the development of a child found delinquent, and the mechanism for delivering that help was to require treatment of youths and their families either in the community or in special institutions. Judge Julian Mack's classic statement of the original theory of the juvenile court suggested that the function of the court was: "not so much to punish as to reform, not to degrade but to uplift, not to crush but to develop, not to make [the delinquent] an offender but a worthy citizen." ${ }^{46}$

Amenability was always the language through which waiver decisions were rationalized and justified, but it also was the language that justified a separate juvenile court. Amenability to treatment was one of the bases for removing cases to the criminal court; blameworthiness was not. But in its origins, the juvenile court failed to develop conceptual meaning, operational criteria, decision standards, or procedures for consistent application of amenability. Thus, there is no positive definition of amenability; we only know who is not amenable. Accordingly, we rarely know the real reasons why decisions to transfer are made. It assembles under the umbrella category of non-amenability, a miscellaneous collection of situations. Thus, the term amenable has lost any distinctive conceptual meaning. The label will be applied whenever the result must be achieved.

Moreover, these ideas change over time. Since amenability is simply the language usual to describe the exclusions, the content and interpretation of amenability have changed over time to reflect prevailing norms about crime, children, and the juvenile court itself. Waiver was the escape hatch for expulsion of adolescents who did not fit the contemporary vision of the juvenile court. ${ }^{47}$

\section{B. The Legal Border}

The past decade has seen every state adopt one or more statutory strategies to increase the number of adolescent offenders whose cases are relocated to the criminal court. ${ }^{48}$ Some states have simplified procedures for judicial waiver, others have

46. Julian Mack, The Juvenile Court, 23 Harv. L. Rev. 104, 107 (1909).

47. David Tanenhaus, The Evolution of Transfer out of the Juvenile Court, in The Changing Borders of Juvenile Justice: Transfer of Adolescents to The Criminal. Court (Jeffrey Fagan and Franklin E. Zimring eds., 2000).

48. Franklin E. Zimring, American Youth Violence (1998). 
expanded the number of cases eligible for judicial waiver, and still others have reassigned the burden of proof for denying waiver from the prosecution to the defense counsel. ${ }^{49}$ In some states, legislatures have excluded specific offenses from juvenile court jurisdiction. Others permit prosecutorial choice of forum between concurrent jurisdictions. Such shifts in the allocation of decision-making authority also reflect contemporary notions regarding the tensions between the judiciary and the prosecutorial function. ${ }^{50}$

While retaining the traditional boundaries of juvenile court jurisdiction, other states have taken steps to make the conditions of confinement harsher: mandatory minimum terms of secure confinement, mandated confinement in secure settings, and recently, confinement in adult institutions. Several states have adopted "blended" sentencing schemes, allowing for the transfer of adolescents to adult institutions when they reach age eighteen. Choosing the criteria for "adulthood" reflects tensions in sentencing policies between retribution and rehabilitation as well as questions about culpability (criminal liability), competence to stand trial, and the risk of continued criminality versus behavioral change. ${ }^{51}$

These developments reflect the presumption in law and policy that those who commit crimes that are remanded to the criminal court, or even those who are charged with such crimes, are fully culpable for their acts. This legal threshold clashes with both emerging empirical evidence on the immaturity of adolescents with respect to both their ability to make informed and nuanced judgments about their behavior and their moral development. ${ }^{52}$ By ignoring these indicia of culpability, the new transfer or waiver policies offend the common law doctrine of incapacity. The modern expression of the common law "infancy defense" states that children lack capacity to form intent to com-

49. Barry C. Feld, The Juvenile Court Meets the Principle of the Offense: Legislative Changes in Juvenile Waiver Statutes, 78 J. CRIM. L. \& CRIMINOLOGY 471 (1987); Youth in Adult Court: Between Two Worlds (Donna M. Hamparian et al. eds., 1982); P. Griffin et al., Trying Juveniles as Adults in Criminal Court: An Analysis of State Transfer Provisions (1998); Robert O. Dawson, Judicial Waiver in Theory and Practice, in The Changing Borders of Juvenile Justice: Transfer of Adolescents to the Criminal Court (Jeffrey Fagan and Franklin E. Zimring eds., 2000).

50. Barry C. Feld, Legislative Exclusions of Offenses From Juvenile Court Jurisdiction: A History and Critique, in The Changing Borders of Juvenile Justice: Transfer of Adolescents to the Criminal Court (Fagan \& Zimring eds., 2000).

51. Fagan \& Zimring, supra note 4.

52. See Laurence Steinberg \& Elizabeth Cauffman, infra note 148. 
mit crimes below the age of fourteen. ${ }^{53}$ Recent research suggests that this incapacity persists through much of adolescence, with juvenile and adult capacities converging not until age 16 or beyond. ${ }^{54}$ Capacity is a prerequisite of "intent," or mens rea, and is the essential element of culpability:

$[M]$ ens rea is the state of mind required to commit a blameworthy act. The concept of legal responsibility, or the capacity to have a culpable state of mind overlaps, in part, with mens rea. Unless the accused has the capacity to be culpable, it is impossible for him to maintain the specific mental state, or mens rea, required for commission of a criminal offense. Legal responsibility may be viewed as a fundamental pre-requisite to the existence of mens rea..... Legal responsibility focuses. . .on whether the accused's deficiencies of judgment distinguish him from others in society such that we do not expect him to comply with the law. ${ }^{55}$

Accordingly, for children accused of crimes and considered for prosecution as an adult, this determination requires a broader inquiry than simply a mens rea analysis, and explicitly points to developmental factors that surround the border between juvenile and criminal court, and that may bear on the ability to form criminal intent. Courts have typically focused on factors such as the child's understanding of the consequences of his act and his ability to act autonomously in determining whether an "infancy defense" is appropriate. ${ }^{56}$ Recently, courts also have considered adolescents' capacity for impulse control. ${ }^{57}$ Criminal law also assumes that offenders make rational, autonomous decisions to commit crimes, ${ }^{58}$ and that culpability or blameworthiness is reduced when adolescents are not rational, autonomous decision makers. ${ }^{59}$ The legal theory of modern transfer policy-that children are blameworthy for specific offenses at specific ages well below the legal age of majority-is

53. See Wayne LaFave, Criminal Law 424, 425 (3d ed. 2000).

54. Laurence Steinberg \& Elizabeth Cauffman, infra note 148; Scott et al., supra note 41, at 136.

55. Andrew Walkover, The Infancy Defense in the New Juvenile Court, 31 U.C.L.A. L.Rev, 503, 537 (1984); Scott et al., supra note 41 at 136.

56. Walkover, supra note 55, at 512.

57. Id. at 559-60; Marty Beyer, Immaturity, Culpability, and Competency in Juveniles: A Study of 17 Cases, CRIM. Just. 27 (Summer 2000); Robert Sheperd, Juvenile Justice: The Rebirth of the Infancy Defense, Criminal Just. 45 (Summer 2000).

58. Elizabeth Scott, The Legal Construction of Adolescence, 29 HofSTRA L. REv. 547, 590 (2000).

59. Id. at 590 . 
disputed by the fact of immaturity among adolescent offenders. "The evidence from developmental psychology challenges the account of adolescence offered by the modern punitive reformers who generally do not accept that relevant differences exist between youthful and adult offenders."60 Adolescents' decisionmaking processes differ from adults, ${ }^{61}$ and their immaturity compromises their ability to weigh the costs and benefits of, and potential consequences of, criminal acts. ${ }^{62}$

In Eddings $v$. Oklahoma, ${ }^{63}$ the U.S. Supreme Court affirmed that the law views adolescents as different intellectually and emotionally from adults. These differences translate into a jurisprudential and decisional paradigm about the selection of a judicial forum, according primacy to their diminished experience, perspective, and judgment. Recent policies that have redrawn the boundary between juvenile and adult court sharply depart from both these jurisprudential foundations and also the weight of modern scientific evidence.

\section{Punishment Perspectives}

Theory and law may be less important in the current debate on the boundary of juvenile justice than two separate but politically confounded concerns with punishment. The first involves the problem of the implicit reduction in culpability for adolescents in the juvenile court, and the attendant discount for adolescents punished as juveniles. Serious crimes committed by young offenders may reflect developmental deficiencies in autonomy and social judgment, suggesting a reduction in their culpability and, in turn, their punishment liability. ${ }^{64}$ But the principle of penal proportionality would require more severe punishment

60. Elizabeth Scott, Criminal Responsibility in Adolescence: Lessons from Developmental Psychology, in Youth on Trial: A Developmental Perspective on JuveNILE JUSTICE 291, 307 (Thomas Grisso \& Robert Schwartz eds., 2000).

61. Daniel Keating, Adolescent Thinking, in AT THE Threshold 54-89 (Shirley Feldman et al. eds., 1990); Elizabeth Cauffman and Laurence Steinberg, Researching Adolescents' Judgement and Culpability, in YOUTH ON TrIAL: A Developmental Perspective on Juvenile Justice 325, 333 (Thomas Grisso \& Robert Schwartz eds., 2000).

62. Barry C. Feld, Abolish the Juvenile Court: Youthfulness, Criminal Responsibility and Sentencing Policy, 88 J. CRIM. L. \& CRIMINology 68, 102-03 (1997). Three psychological factors impact adolescent decision making: responsibility, comprehension of situational complexity, and ability to control impulsivity. Scott et al., supra note 41 , at 161 .

63. 455 U.S. 104 (1982)

64. Scott et al., supra note 41 , at 137. 
than that available in the juvenile court. ${ }^{65}$ There are some crimes committed by adolescents for which the most stringent juvenile court punishments require punitive responses beyond the limitations of the juvenile court, punishments that fall far short of the normative demand for punishment for such crimes regardless of the age of the offender. ${ }^{66}$ Recent revisions of the law are expressions of the primacy of penal proportionality over reduced culpability of adolescent offenders. In this view, the traditional preoccupation with rehabilitation in the juvenile court, with its limitations on punishment liabilities, deprecates the moral seriousness of crimes and offers inadequate retribution. ${ }^{67}$

The second is the utilitarian concern with public safety. Critics of the juvenile court question whether the juvenile court can either rehabilitate chronic and violent young offenders at all, or if it can do so while simultaneously protecting public safety. ${ }^{68}$ Citing rising juvenile crime rates beginning in the 1970 s, they contend that criminal court sanctions provide greater community protection and more effectively deter future crime. ${ }^{69}$ Ultimately, for those who view the debate from this perspective, the controversy about jurisdiction for adolescent offenders is part of the more general question about the relative efficacy of juvenile versus criminal court interventions.

Supporters of the juvenile court argue that youth violence is a transitory adolescent behavioral pattern that, for most adolescents, is unlikely to escalate into more serious or persistent crime. ${ }^{70}$ Given "room to reform,"

65. Franklin E. Zimring, The Law's Construction of Children's Culpability, in Competence, Culpability, and Youth: Toward a Coherent System of JuveNILE Justice (Robert Schwartz \& Thomas Grisso eds.) (forthcoming).

66. Franklin E. Zimring, The Punitive Necessity of Waiver, in CHANGING Borders of Juvenile Justice: Transfer of Adolescents to the Criminal Court, supra note 38, at 207.

67. See, e.g., FELD, supra note 36.

68. Id.

69. See, e.g., James Q. Wilson, Crime and Public Policy, in CRIME 489 (James Q. Wilson \& Joan Petersilia eds., 1997).

70. See, e.g., Donna M. Hamparian, The Violent Few (1978) (showing that fewer than five percent of juvenile offenders are chronically violent, and only a small fraction of them go on to adult criminal careers); ELLIOTT CURRIE, Crime and Punishment in America (1998) (showing that evidence of sustained criminality by adolescents reflects the absence of effective interventions).

71. There is overwhelming evidence that most adolescents are unlikely to sustain juvenile crime beyond their teenage years given opportunities for change via natural maturation or through the benefits of effective intervention programs. See, e.g., Franklin E. Zimring, The Changing Legal. World of AdoLESCENCE (1981); Franklin E. Zimring, The Treatment of Hard Cases in American 
as juveniles without the "disfiguring" punishments of the adult courts. That is, they argue that adolescent offenders can benefit from the treatment services of the juvenile justice system. These services reduce juvenile criminal behavior through developmental processes and therapeutic interventions, which pose minimal threat to public safety and allow juveniles to avoid both the lasting stigma of a criminal conviction and the trauma of adult punishment. Although championing a rehabilitative regime whose empirical foundations are suspect, proponents of juvenile court intervention do not accept the criticisms of rehabilitative programs. They argue instead that weak evaluation research or poor program quality mask the natural strengths of juvenile corrections. $^{72}$

\section{Empirical Realities of Criminalizing Delinguency}

Lack of empirical information has not deterred legislators from changing the boundaries of juvenile and adult court. There is little information on the comparative advantages of juvenile versus criminal court jurisdiction on either increasing the severity and likelihood of punishment, or on rates of recidivism. Controlled studies comparing sentencing patterns in juvenile and criminal court are rare. Studies comparing the crime control benefits of criminalizing delinquency are even rarer. The available evidence provides a less than convincing case for either penal proportionality in adult sentencing of juvenile offenders, or in the utilitarian advantages of lower crime rates for adolescents whose cases are relocated to the adult court.

\section{A. Penal Proportionality}

Whether the criminalization of youth crime has resulted in more certain or severe sanctions is not at all clear. Martin Roysher and Peter Edelman ${ }^{73}$ examined dispositions and placements under the New York Juvenile Offender Law, ${ }^{74}$ which relo-

Juvenile Justice: In Defense of Discretionary Waiver, 5 Notre Dame J.L. ETHics \& Pub. Pol'y 267 (1991); Zimring, American Youth Violence, supra note 48, at 69-87.

72. See, e.g., Jeffrey Fagan, Social and Legal Policy Dimensions of Violent Juvenile Crime, 17 Crim. Just. \& Behav. 93 (1990); Ted Palmer, A Profile of CorRECIIONAL EFFECTIVENESS (1994).

73. Martin Roysher \& Peter Edelman, Treating Juveniles as Adults in New York: What Does it Mean and How is it Working?, in REAdings In Public Policy (John C. Hall et al. eds., 1981).

74. In 1978, New York State enacted legislation that gave original jurisdiction to the criminal court for specific felony offenses committed by youths below sixteen years of age. This statute was known as the Juvenile Offender 
cated original jurisdiction to the Criminal Court for juveniles charged with violent crimes. They found that sanctions were no more severe in criminal court, and in many cases were actually less harsh. While Roysher and Edelman followed samples of offenders, Professor Simon Singer ${ }^{75}$ used aggregate data on counties across New York State to arrive at much the same conclusion. James Howell and colleagues $(1995)^{76}$ similarly found that youthful offenders (eighteen to twenty-five years of age) confined by the California Youth Authority for violent offenses were actually incarcerated longer than juveniles or adults sentenced to the (adult) Department of Corrections for the same crimes.

Comparing case outcomes in three different jurisdictions, Peter Greenwood and his colleagues ${ }^{77}$ found no evidence of a "leniency gap" for young offenders adjudicated and sentenced in criminal courts in three. Cary Rudman and his colleagues ${ }^{78}$ found that sanctions in juvenile and criminal court for juveniles charged with violent crimes in five urban court jurisdictions were equally certain, but juveniles waived to criminal court received harsher sanctions because there was no age limitation on sentence length for adult offenders. Professor Margaret Bortner ${ }^{79}$,

Law, and the offenders it covered were called “J.O.'s." See Simon I. Singer \& David McDowall, Criminalizing Delinquency: The Deterrent Effects of the New York Juvenile Offender Law, 22 L. \& Soc'y Rev. 521 (1988); Merril Sobie, The Juvenile Offender Act: Effectiveness and Impact in New York Juvenile Justice System, 26 N.Y.L. SCH. L. Rev. 677 (1981), and Simon I. Singer \& Charles P. Ewing, Juvenile Justice Reform in New York State: The Juvenile Offender Law, 8 LAw \& PoL'y 463 (1986). Singer also found wide differences in the selection of jurisdiction for juvenile offender cases, with judges often electing to use the "transfer back" provisions to return J.O. cases to the juvenile (Family) court. Variation in the return rates was attributable to bureaucratic variation, differences between courts in local cultural norms regarding juvenile crime, geographic and structural variation between counties, the criminal courts' working group structures as tightly or loosely coupled systems, the severity of juvenile offender cases in the overall stream of cases, discretionary decision making that assigns varying weights to family and other social characteristics, and practical fiscal considerations. See Simon I. Singer, The Case Processing of Juvenile Offenders in Criminal Court and Legislative Waiver in New York State, Final Rep. Washington, D.C.: Office of Juvenile Justice and Delinguency Prevention, U.S. Dep't of JusT. NCJ 148013 (1994).

75. See Simon I. Singer, Recriminalizing Delinquency (1996).

76. Sourcebook on Serious, Violent \& Chronic Juvenile Offenders (James C. Howell et al. eds., 1995).

77. Peter W. Greenwood et al., National Institute of Justice, Fac tors Affecting Sentence Severity for Young Adult Offenders (1984).

78. Cary Rudman et al., Violent Youth in Adult Court: Process and Punishment, 32 CRIme \& Deling. 75 (1986).

79. M.A. Bortner, Traditional Rhetoric, Organizational Realities: Remand of Juveniles to Adult Court, 32 CRIME \& Deline. 53 (1986). 
examining a broader offense range in the Maricopa County (Phoenix), Arizona courts, found that juveniles do not receive longer sentences from the criminal court than they would from juvenile court. She found that juvenile court officials viewed the waiver (remand) process as a legal mechanism for staving off criticisms of the entire juvenile justice system.

Some studies (e.g., Thomas and Bilchik, ${ }^{80}$ Houghtalin and Mays $^{81}$ ) found that juveniles are treated more severely when sentenced in criminal court than juvenile court. Not only do the studies find that sanctions are harsher, but case attrition for juveniles in criminal court is actually lower than for adults. However, like other studies, the samples of juveniles in criminal court in these studies are selective and skewed toward more serious offenses based on prosecutorial screening (for concurrent jurisdiction cases) and judicial waivers. These processes occur in British courts as well. ${ }^{82}$ There, Crown Court judges were reluctant to impose more severe sanctions in remanded cases involving youth ages fifteen to twenty-one convicted of "indictable" (i.e., felony) offenses.

Results of controlled studies are inconsistent. For example, Professors Donna M. Bishop, Lonn Lanza-Kaduce, and Charles Frazier compared sentencing patterns of 2,738 adolescents transferred to criminal court in Florida in 1987 with a matched sample of adolescents retained in the juvenile court. ${ }^{83}$ Approximately thirty percent of the transferred cases were sentenced to state prison, most for periods of one to five years, compared to $20 \%$ in the juvenile court. Moreover, average incarceration terms of three months were far lower for adolescents in juvenile corrections placements compared to prison sentences imposed on transferred cases by the criminal courts. ${ }^{84}$

Research in the Hennepin County (Minneapolis), Minnesota juvenile court included all juveniles $(n=330)$ from 1986 to 1992 against whom prosecutors filed during a reference (waiver)

80. Charles W. Thomas \& Shay Bilchik, Prosecuting Juveniles in Criminal Courts: A Legal and Empirical Analysis, 76 CRIME \& Deline. 393 (1991).

81. Marilyn Houghtalin \& G. Larry Mays, Criminal Dispositions of New Mexico Juveniles Transferred to Adult Court, 37 CRIME \& Deline. 393 (1991).

82. Home Office, Criminal Statistics, England and Wales, 1982, London: Her Majesty's Stationary Office (1983).

83. D.M. Bishop et al., The Transfer of Juveniles to Criminal Court: Does it Make a Difference?, 42 CRIME \& Deline. 171 (1996).

84. Dates of entry and release from juvenile corrections placements were not available in the Florida study. Instead, the researchers assigned the average time served across all juvenile corrections facilities. Id. at 178. 
motion. ${ }^{85}$ More than two in three $(n=215,65 \%)$ were waived to the adult court. Of those retained in the juvenile court, more than half $(54 \%)$ were sentenced to some type of long-term juvenile correctional facility, and an additional $20 \%$ to some type of juvenile short-term local residential program. Most $(82 \%)$ of the waived youths were sentenced to a local (jail) or state (prison) correctional institution. But the criminal courts also stayed the incarceration terms of virtually all youths sentenced to local jails. Among convicted youths, the incarcerations were still higher, even after controlling for offense severity. The authors conclude: "[a]lthough the waiver process selects youths on the basis of seriousness, the differences in the rates of dismissal, conviction and incarceration between the two systems are striking." 86

Sentence lengths for incarceration in the Minnesota study also were longer for youths sentenced in the criminal court, but only for "presumptive" offenses. ${ }^{87}$ Adolescents waived and convicted on presumptive sentences received average incarceration sentences of 966 days compared to 266 days for adolescents retained in the juvenile court. ${ }^{88}$ For non-presumptive offenses, adolescents in the juvenile court received longer sentences (182 days) compared to waived cases (134 days). Non-presumptive cases were more likely to involve non-violent crimes.

A third controlled study compared matched samples of $(n=810)$ offenders charged with armed robbery or burglary offenses, ages fifteen to sixteen, in adjacent counties in two states where youths of similar ages and charges are sanctioned in differ-

85. Mary Rassmussen Podkopacz \& Barry C. Feld, Judicial Waiver Policy and Practice: Persistence, Seriousness and Race, 14 LAw \& InEQUalrTy 73 (1995); Mary Rassmussen Podkopacz \& Barry C. Feld, The End of the Line: An Empirical Study of Judicial Waiver, 86 J. CRIM. LAW \& CRIMINoloGy 449 (1996) [hereinafter Podkapacz \& Feld, End of the Line].

86. See Podkopacz \& Feld, End of the Line, supra note 85, at 487.

87. The 1980 amendments to the Minnesota juvenile code allowed prosecutors to establish a prima facie case, or rebuttable presumption, of nonamenability and dangerousness by proving that a youth possessed various combinations of present offense seriousness and prior offenses. See MinN. Stat. $\S 260.125$ (3) (1992). The rebuttable presumption shifts the burden of proof to the party opposing the prima facie case to avoid transfer. See Barry C. Feld, Juvenile Court Legislative Reform and the Serious Young Offender: Dismantling the Rehabilitative Ideal, 65 MINN. L. REv. 167, 209-10 (1981).

88. However, for adults, these averages included sentences in local jails and state prisons. For offenders charged with presumptive offenses in criminal courts, prison sentences were ordered in more than half $(51 \%)$ of the cases, with a median length of 1,459 days. Most non-presumptive cases in criminal courts were sentenced to local jails, where the maximum possible sentence is 365 days. See Podkopacz \& Feld, End of the Line, supra note 85, at 488. 
ent court jurisdictions. ${ }^{89}$ Cases selected from two counties in southeastern New York were filed in the criminal court, and cases from two counties in northeastern New Jersey were filed in the juvenile court. ${ }^{90}$ Offenders charged with robbery were more likely to be convicted in criminal court; there were no differences for offenders charged with burglary. Among those convicted, incarceration sentences were more likely in the criminal court for both charge categories. Nearly half of the cases involving robbery charges in the criminal court $(46.4 \%)$ were sentenced to prison or jail, compared to $18.3 \%$ in the juvenile court. A similar trend was found for burglary cases: $46.5 \%$ received incarceration sentences in the criminal court, compared to $23.8 \%$ in the juvenile court. However, sentence lengths for incarcerated offenders did not differ significantly, either by charge or court jurisdiction. ${ }^{91}$

Recent efforts to criminalize delinquency have sought in part to reduce the perceived punishment gap between juvenile and criminal courts. At least for the most serious crimes committed by adolescents, imposing harsher punishments expresses normative views of the moral obligations of penal proportionality in setting the punishment costs, and obviates any discount in punishment based on theories of diminished culpability or immatur-

89. Jeffrey Fagan, The Comparative Impacts of Juvenile and Criminal Court Sanctions on Adolescent Felony Offenders, 18 LAw \& PoL'Y 77 (1996) [hereinafter Comparative Impacts].

90. See id. at 85-86. The counties were matched on their rank order within their respective states on demographic characteristics associated with incarceration and crime rates. See also Robert J. Sampson \& John H. Laub, Structural Variations in Juvenile Court Processing: Inequality, Social Control, and the Underclass, 27 LAw \& Soc'y Rev. 285 (1993).

91. See Comparative Impacts, supra note 89, at n.9. Similar to the Florida and Minnesota studies, precise incarceration terms were difficult measure. To measure actual sentence length for incarceration sentences, the time served was estimated as one-third of the term of commitment. This estimate was based on aggregate data on length of stay in New Jersey Department of Corrections juvenile facilities for 1981-1983. It included commitments of up to thirty-six months or age nineteen for state training school, and forty-five days for remand to local juvenile detention centers for post-adjudication incarceration. In New York, sentences to either Department of Corrections facilities or commitments to Division for Youth facilities (as Youthful Offenders) were stated with minimum and maximum terms. The minimum sentence was used to calculate sentence length. This again was based on length of stay information provided by the New York State Department of Corrections for inmates received in 1981-1983 who were less than nineteen years of age. Additionally, sentences were standardized within the sample for both maximum time and time served, providing a correction for inter-state differences in paroling and early release practices. 
ity of adolescents. ${ }^{92}$ Three recent studies suggest that intentions may exceed implementation when it comes to closing the punishment gap. Under three different sorting mechanisms for placing adolescent offenders in the criminal court, adolescents convicted in the criminal court were more likely to be incarcerated, net of offense and offender variables, than youths adjudicated in the juvenile court. While incarceration is more likely for youths tried as adults, the length of punishment is no different on either side of the jurisdictional divide.

\section{B. Substantive Punishment}

However, while incarceration terms may not differ meaningfully, substantive punishment of adolescents in adult corrections may be far harsher than punishment as a juvenile. The distinctions between adult and juvenile corrections facilities are evident in both overt and subtle ways. Although remedial programs may be found in many prisons, adult correctional facilities emphasize retribution and control. Correctional staff wear uniforms and are referred to as "correctional officers." Adult prisons also carefully distinguish staff involved in remedial programs, such as education and counseling, from custodial staff.

In contrast, most juvenile corrections facilities integrate remediation of social deficits and behavioral problems with custody and control. ${ }^{93}$ Juvenile corrections staff use the terminology of remediation. Titles such as "social worker" or "counselor" are used, unlike the "correctional officer" (or "CO") titles of guards in adult prisons. Furthermore, uniforms are uncommon in juvenile institutions.

The difference between juvenile and adult institutions has been characterized as a "treatment-custody dichotomy." ever, efforts to close a leniency gap are more focused on the length of punishment, not the conditions. But harsher conditions may often be an ancillary consequence of sentencing juveniles as adults. A study by Martin Forst and colleagues is one of the few studies of the "treatment-custody dichotomy" that compares the experiences of adolescents incarcerated as

92. Franklin E. Zimring, Penal Proportionality for the Young Offender: Note on Immaturity, Capacity, and Diminished Responsibility, in Youth ON TRIAL: A Devel. opmental Perspective on Juvenile Justice 4 (2000).

93. See D. Parent, Office of Juv. Just. \& Deline. Prevention, CondiTIONS OF CONFINEMENT 147 (1991).

94. Barry C. Feld, The Juvenile Court Meets the Principle of the Offense: Legislative Changes in Juvenile Waiver Statutes, 78 J. CRIM. L. \& CRImINOLOGY 471 (1987). 
juveniles with a matched sample incarcerated as adults. ${ }^{95}$ In interviews with fifty-nine youths in juvenile corrections facilities and eighty-one adolescents in state prisons, the juvenile corrections sample more often reported staff as helpful in controlling behavior and achieving personal goals. Using scales of four dimensions of remediation climate, ${ }^{96}$ respondents in juvenile facilities reported a significantly higher orientation toward remediation compared to respondents in state prisons. ${ }^{97}$

Placement of adolescents in adult corrections facilities also exposes them to high levels of violence. ${ }^{98}$ Adolescents in adult institutions have a relatively low and weak position in the social hierarchy of prison, and physical vulnerability to attack accompanies their low status. ${ }^{99}$ In the Forst et al. study, the state prison group reported higher rates of physical assaults by staff and inmates: rates of sexual victimization were nearly five times higher for youths in state prisons $(8.6 \%)$ compared to youths in training schools $(1 \%) .{ }^{100}$ These hidden dangers are unintended consequences of legislative efforts to close the leniency gap.

\section{Returns to Crime Control}

The utilitarian perspective on criminal sanctions for adolescents invokes the framework of deterrence. ${ }^{101}$ Common sense guides the deterrence doctrine: most individuals would rather

95. Martin Forst et al., Youth in Prisons and Training Schools: Perceptions and Consequences of the Treatment-Custody Dichotomy, 40 Juv. \& FAM. CT. J. 1 (1989).

96. Alden D. Miller \& Lloyd E. Ohlin, Delineuency and Community (1985); Jeffrey Fagan \& Martin Forst, Risks, Fixers and Zeal: Treatment Innovation and Implementation for Violent Juvenile Offenders, 76 PRison J. 5 (1996). The scales measured perceptions of the extent to which youth-staff interactions supported: (a) the development of social interactional skills (Social Networks), (b) promoted fairness and consistency in the application of rewards and sanctions for behavior (Social Learning), (c) provided opportunities to develop social skills and marketable job skills (Youth Opportunities), and (d) emphasized behavioral goals (Goal Orientation).

97. See Forst et al., supra note 95, at 9.

98. Paul W. Keve, The Quicksand Prison, 63 Prison J. 47 (1983); JoHN IRWIN, JaILS: MANAGING THE UNDERClass (1985); Z. Eisikovits \& M. Baizerman, Doin'Time': Violent Youth in a Juvenile Facility and in an Adult Prison, $6 \mathrm{~J}$. OFFENDER Counseling, Services \& Rehabilitation 5 (1983); Daniel lockwood, Prison Sexual Violence (1980); E. Van den HaAg, Punishing Criminals (1975).

99. Richard S. Jones \& Thomas J. Schmid, Doing Time: Prison ExperiENCE AND IdENTITY AMONG First-Time INMATES 78-79, 84-86 (2000).

100. See Forst, supra note 95, at 10 tbl.5.

101. For general reviews, see Kirk R. Williams \& Richard Hawkins, Perceptual Research On General Deterrence, 20 LAw \& Soc'y Rev. 545 (1986); Franklin E. Zimring, \& Gordon J. Hawkins, Deterrence: The Legal Threat in Crime ConTROL (1973). 
avoid prison and accordingly are discouraged from criminal behavior. ${ }^{102}$ Yet, despite a growing body of literature on general deterrence, there has been almost no research on the general or specific deterrent effects of criminal court sanctions for adolescent offenders.

General deterrence is the threat or imposition of sanctions on one person to demonstrate to the broader public the expected costs of criminal acts. General deterrent effects depend on the probability that offenders view their behaviors as likely to be detected and punished. General deterrence also depends on the perception by offenders that the punishments will be severe (Piliavin, Gartner, Thornton and Matsueda 1986; Nagin and Paternoster 1991). That is, the threat of punishment will regulate perceptions of crime costs and the marginal gains from crime opportunities. ${ }^{103}$ Specific deterrent effects result from experiences of punishment costs (pain or deprivation of liberty), and offenders will choose not to pay that penalty or cost again. ${ }^{104}$ Professors Franklin Zimring and Gordon Hawkins, in their seminal work on deterrence, point out that specific deterrence requires social actors to rationally calculate the costs and benefits of crime, a notion that Akers has explicitly linked to social learning processes. ${ }^{105}$ Ultimately, the deterrent effects of sanctions depend on their perceived certainty and severity. This is commonly referred to as perceptual deterrence. ${ }^{106}$

Both general and specific deterrence frameworks also suggest that individuals will commit fewer crimes if they perceive that the benefits of compliance outweigh the punishment costs of legal sanctions. However, the salience of these societal benefits depend on the individual's access to material and social rewards, as well as the premium the person associates with those rewards. The availability of these rewards varies across communities, reflecting variation in local labor markets and other eco-

102. J.L. Miller \& Andy B. Anderson, Updating the Deterrence Doctrine, $77 \mathrm{~J}$. Crim. L. \& Criminology 418 (1986).

103. Samuel Kramer, An Economic Analysis of Criminal Attempt: Marginal Deterrence and the Optimal Structure of Sanctions, 81 J. CRIM. L. \& CRIMINOLOGY 398 (1990).

104. See also George S. Bridges \& James A. Stone, Effects of Criminal Punishment on Perceived Threat of Punishment: Toward an Understanding of Specific Deterrence, 23 J. Res. CRIME \& Deline. 207 (1986); see also Miller \& Anderson, supra note 102 , at 438.

105. See Ronald A. Akers, Toward an Integration of Social Learning, Rational Choice, and Deterrence Perspectives, 82 J. CRIM. L. \& CRImINolocy 653 (1990).

106. See Williams \& Hawkins, supra note 101; Daniel Nagin, Criminal Deterrence Research at the Outset of the Twenty-First Century, 23 CrImE \& Just. 51, 57 (1998). 
nomic conditions. In other words, specific deterrence is likely to depend on the individual actor's social context and prior experiences to calculate the opportunity costs of legal behavior, the perceived costs, and likelihood of punishment, and the marginal benefits of illegal monetary gains. Accordingly, legal punishments may interact with both an offender's human capital ${ }^{107}$ and with the social context of his or her daily interactions, to produce or inhibit deterrent effects.

There has been little systematic research comparing the deterrent effects of juvenile and criminal court sanctions on recidivism of adolescent offenders. Typically, these studies compare samples of youths transferred from juvenile to adult jurisdiction within a single jurisdiction, introducing sample selection biases that confound comparisons of the two types of proceedings and sanctions. Others compare offenders from different jurisdictions, introducing important contextual influences that interact with the deterrent effects of punishment. ${ }^{108}$ Only three studies have systematically compared recidivism rates for adolescents sentenced as juveniles or adults, addressing the methodological problems in earlier studies.

In the Minnesota study, $58 \%$ of the transferred youths committed new offenses within two years of conviction, compared to $42 \%$ of the youths retained in the juvenile court, a statistically significant difference. ${ }^{109}$ Offenses were more serious among the waived sample: over $85 \%$ were convicted of felony offenses against persons or property, compared to $63 \%$ of the waived sample. The frequency of new offenses was higher for the waived sample as well. The analysis did not control for the sorting process used by prosecutors to refer juveniles for transfer to the adult court. Accordingly, the transferred population had substantively different and more serious prior incarceration records compared to the retained youths, in terms of both prior offenses and failures in prior treatment efforts. ${ }^{110}$ Thus, prosecutorial selection in this case may serve as a proxy for criminal propen-

107. Human capital includes educational attainment, job skills and experience, and other personal attributes that translate into making an individual a valuable and desired commodity in a labor market.

108. John C. Hagan \& Kristin Bumiller, Making Sense of Sentencing: A Review and Critique of Sentencing Research, in RESEARCH ON SENTENCING: THE SEARCH FOR REFORM (Alfred Blumstien et al. eds., 1983); see also Charles R. Titrtle, Sanctions and Social Deviance: The Question of Deterrence (1980); Charles R. Tittle, Evaluationg the Deterrent Effects of Criminal Sanctions, in Handbook Of Criminal Justice Evaluation 381 (Malcolm Klein \& Kathie Teilmann eds., 1980).

109. See Podkapacz \& Feld, End of the Line, supra note 85, at 490.

110. Id. at 491 . 
sity, and the differences between the samples may reflect more about that propensity than the differential effects of court jurisdiction. But two other possible explanations are offered for the elevated recidivism rates of the criminal court population: socialization to criminal norms and learning criminal skills in adult correctional institutions, and therapeutic returns of juvenile corrections interventions. This explanation is consistent with other studies that illustrate differences in substantive punishment between juvenile and adult corrections. ${ }^{11}$

The Florida study shows a similar pattern of higher offending rates for youths transferred to the adult court. ${ }^{112}$ This study used a case matching procedure to control for the selection and sorting processes that allocate adolescents to the juvenile or adult court. Cases were matched on seven criteria: (1) most serious offense for which the transfer was made, (2) the number of counts included in the bill of information for the committing offense, (3) the number of prior referrals to the juvenile court, (4) the most serious prior offense, (5) age at the time of the committing offense, (6) gender, and (7) race (coded dichtomously as white or non-white). The matching process is critical to the validity of statistical inferences of sample differences that exclude selection bias. ${ }^{113}$ Matches were successful for the first six variables, but transfers including matches for race were less successful. Only two-thirds of the white transfers could be matched to white nontransfers, and only about half of the non-white transfers could be matched to non-white nontransfers. ${ }^{114}$ When the race criterion was relaxed, successful matches were obtained in $92 \%$ of the cases.

Recidivism rates were far higher for transferred cases within the first three years following conviction: $30 \%$ of the transferred youths were rearrested, compared to $19 \%$ of the juvenile court sample. ${ }^{115}$ But in a seven year follow-up, rearrest rates were comparable for the two groups: $42 \%$ of the transfers were rearrested, compared to $43 \%$ of the juvenile court sample. ${ }^{116}$ The difference in long-term recidivism rates was not significant. However, differences for specific offense types were evident. Recidivism

111. Cf. Forst, supra note 95.

112. See Bishop et al., supra note 83, at 182.

113. Jeffrey A. Fagan, Natural Experiments, in Measurement Issues IN CRIMINOLOGY 108 (Kimberly L. Kempf ed., 1990).

114. Lawrence Winner et al., The Transfer of Juveniles To Criminal Court: Reexamining Recidivism Over the Long Term, 43 CrIme \& Delinguency 548, 550 (1997) [hereinafter Winner et al., Reexamining Recidivism].

115. See Bishop et al., supra note 83 , at 182.

116. See Winner et al., supra note 114, at 551 . 
rates were higher for nontransferred felony property offenders; there were no differences for cases involving felony violence. For all other crime categories, rearrest rates were higher over the longer follow-up period for transferred cases. ${ }^{17}$ Using multivariate analysis to control for the matching criteria, there was a weak but statistically significant effect of transfer on rearrest: after controlling for offense and offender characteristics, transferred cases were 1.59 times more likely to be rearrested over the follow-up period. ${ }^{118}$

Analyses of time to first rearrest showed that rearrest risks were higher for transferred cases during the first 1,500 days of the follow-up period, but the risks were no different thereafter. ${ }^{119}$ Using survival analysis to characterize differences in the time to rearrest, and controlling for offense types, transferred cases were more likely to be rearrested over the follow-up period for all offense types except property offenses. The authors conclude that, similar to the short-term follow-up, this longer-term follow-up showed that "transfer was more likely to aggravate recidivism than to stem it." 120

The natural experiment comparing adolescents from New York and New Jersey produced similar results. ${ }^{121}$ In this study, recidivism rates were computed for adolescent felony offenders adjudicated in juvenile court in New Jersey with matched cases sentenced in the adult court in New York. For robbery offenders, rearrest rates were higher for cases adjudicated in the criminal courts (chi-square $=6.757, \mathrm{p}<.009$ ) ${ }^{122}$ However, rearrest rates did not differ for burglary offenders by court jurisdiction. The pattern for reincarceration was similar. Robbery cases in the criminal court cohort were reincarcerated more often $(56.2 \%)$ than the juvenile court robbery cohort $(40.9 \%)$ (chi-square $=$ $16.56, \mathrm{p}<.001) .{ }^{123}$ There were no significant differences in reincarceration rates for burglary offenders.

The annualized rate of rearrest offending was computed for offenders with at least one rearrest (for a new criminal violation). ${ }^{124}$ Differences between juvenile and criminal court cases

117. Id. at 552 .

118. Id. at 553 .

119. Id. at 556 .

120. Id. at 558 .

121. See Fagan, supra note 31.

122. Id. at 92 .

123. Id. at 93 .

124. The re-offending rearrest rates were calculated by annualizing total arrests over the time at risk during the follow-up period. Time reincarcerated was excluded from the re-offending "window." Incarceration times for subse- 
mirrored the patterns observed for other crime indicators. There were significant differences in rearrest rates for robbery offenders in criminal court compared to robbery offenders in juvenile court (2.85 rearrests per year at risk versus 1.67 rearrests per year at risk) $(\mathrm{F}=11.24, \mathrm{p}<.001)$. There were no significant differences in the rates for burglary offenders by court jurisdiction. ${ }^{125}$

Another comparison examined the number of days until rearrest. This measure, called failure time or survival analysis, ${ }^{126}$ showed that for robbery offenders in the criminal court, rearrests occurred at an average of 457 days after first release to the street, compared to 553 days for robbery offenders in the juvenile court $(\mathrm{F}=4.662 ; \mathrm{p}<.05)$. For burglary offenders, there was no significant difference between juvenile and criminal court cases. A Cox regression model was used to assess the effects of court jurisdiction and sentence length on the hazard of rearrest within three years of street time, controlling for the effects of case (offense and offender) characteristics. ${ }^{127}$ The parameters showed that the hazard of (or risk of) rearrest was $29 \%$ lower for adolescents sentenced in the juvenile court compared to criminal court cases, after controlling for sentence length. ${ }^{128}$ When specific types of rearrest were considered, the same comparative advantage was observed for juvenile court sanctions for violent offenses, for other felony offenses, and for misdemeanors. Only for drug offenses did the model show a comparative advantage

quent convictions were determined using the same procedures for calculating minimum sentences. Suspended sentences were not included in the calculation of subsequent incarceration times. Sentences to time served were estimated by computing the interval between the rearrest date and the sentencing date for the rearrest event. Id. at nn.15-16.

125. See Fagan, supra note 31, at 93.

126. Peter Schmidt \& Anne Dryden Witte, Predicting Recidivism Using Survival Models (1989).

127. Hazard models estimate the probability that an individual will fail during a given time period. Hazard analyses simultaneously estimate the likelihood of two dimensions of recidivism: its prevalence during a given time period, and the interval until rearrest occurs. The Cox procedure permits testing of specific hypotheses by including covariates in the model and testing for their significance against a model with no predictors. See David R. Cox, Regression Models and Life Tables, 34 J. Of THe Royal Stat. Soc'y 187 (1972); Paul D. Allison, Event History Analysis: Regression for longitudinal Data (1984); William R. Greene, Econometric Analysis (1990).

128. The percent reduction in hazard of rearrest is based on the exponentiated coefficient $[\operatorname{Exp}(B)]$. An $\operatorname{Exp}(B)$ is computed for each independent variable. It indicates the percentage change in the hazards of rearrest associated with a unit change in that independent variable. 
for criminal court punishment. ${ }^{129}$ Finally, tests of interactions of sentence length by court jurisdiction yielded no significant effects. $^{130}$

Thus, the comparative advantage of juvenile court sanctions in controlling crime among adolescent felony offenders seems to reflect its unique correctional context, and is independent of the length of punishment. The substantive dimensions of punishment in adult correctional facilities offers an important clue to explaining the increase in crime propensity among adolescents that follows punishment as an adult and with adults. Increasing the length of confinement offers no return to crime control for this population. Moreover, punishment in the adult correctional system seems to raise the risk of rearrest, an iatrogenic effect that contradicts the predictions of deterrence theory. There is a consistent pattern of higher rates of criminal offending among adolescents punished as adults compared to adolescents punished as juveniles. ${ }^{131}$ These results were obtained across a range of sampling and measurement conditions, and the effects were identified using different analytic methods. Whatever the symbolic gains from sentencing adolescents as adults, these gains are discounted, if not reversed, by the increased public safety risks of substantive punishment of juveniles as adults.

129. See Fagan, supra note 31 , at $96-98$.

130. Id. at 99.

131. Criminological research cites several noteworthy examples of iatrogenic effects of criminal sanctions. Assailants in misdemeanor domestic violence cases who are arrested are rearrested more often and more quickly than a randomly assigned control group who were warned and released by police. The effect was specific to offenders with "low stakes in conformity," as measured by their employment (unemployed) and marital (unmarried, cohabitating) status. See Lawrence Sherman, Policing Domestic Violence (1992); Lawrence Sherman et al., From Initial Deterrence to Long-term Escalation: Short Custody Arrest for Poverty Ghetto Domestic Violence, 29 Cruminology 821 (1991). Misdemeanor domestic violence assailants who received temporary restraining orders were rearrested more often compared to a matched sample who were given no such orders. See Adelle Harrell et al., Court Processing and the Effects of Restraining Orders for Domestic Violence Victims, Grant 90-12L E-089 (State Justice Institute May 1993) (final report). Drug offenders receiving prison sentences were more likely to be rearrested and were rearrested sooner, compared to a matched sample of drug offenders who received noncustodial sentences, controlling for characteristics of the offense and offender. See Jeffrey Fagan, Do Criminal Sanctions Deter Drug Offenders?, in Drugs and CRIMInal Justice: Evaluating Public Policy Initlatives 188 (Doris Mackenzie \& Craig Uchida eds., 1994). 


\section{Summary}

Reviewing two decades of research on transfer, Professor Donna Bishop condemns the "recent and substantial expansion of transfer" as harmful and ineffective. ${ }^{132}$ Two decades of legislative activism have sharply increased the number of juveniles prosecuted as adults and sentenced to adult criminal punishments. Many of them are below the age of 17 , had no history of violence that would pose a public safety threat, and were convicted of nonviolent or misdemeanor crimes. ${ }^{133}$ The increase in transfer has disproportionately affected minority youths, well in excess of their contribution to the population of adolescent offenders. ${ }^{134}$ The weight of empirical evidence strongly suggests that there are no general deterrent effects of increasing the scope of transfer on the incidence generally of serious juvenile crime. ${ }^{135}$ Nor are there marginal specific deterrent effects on offending rates of youths transferred to and sentenced in the adult court. ${ }^{136}$ In fact, Bishop shows that in two studies, juveniles prosecuted as adults had higher rates of rearrest for serious felony crimes such as robbery and assault, were rearrested more quickly, and were more often returned to incarceration. ${ }^{137}$ The broad reach of new transfer laws and policies captures both those whose crimes and reoffending risks may merit harsher punishment, but also many more who are neither chronic nor serious offenders, pose little risk of future offending, and who seem to be damaged by their exposure to the adult court. Whatever the gains of shortterm incapacitation, they are more than offset by the iatrogenic and toxic effects of adult punishment for the larger group of adolescent offenders.

\section{Developmental. Insights}

In this section, we begin the search for explanations of the elevated risks of adolescent crime following harsher punishment. We apply our understanding of the contrasting incarceration experiences of adolescents in these two punishment contexts to theories of criminal behavior based on developmental psychology. We include dimensions of cognitive and emotional develop-

132. Donna M. Bishop, Juvenile Offenders in the Adult Criminal Justice System,

27 Crime and Justice: A Review of Research 81, 85 (2000).

133. Id. at 85.

134. Id at 85 .

135. Id. at 86. But see Steven Levitt, Juvenile Crime and Punishment, $106 \mathrm{~J}$. Pol. EсONOMY 1156 (1998).

136. Bishop, supra 132 at 132-34.

137. Id. 
ment. While others have applied developmental theory to deconstruct punitive responses to adolescent antisocial behavior, ${ }^{138}$ theories of adolescent development are applied here to explain the diverging developmental trajectories of adolescents adjudicated and punished under starkly different conditions. We find the explanation for the elevated risks of crime and incarceration following adult punishment in the tension between theories of adolescent development and theories of deterrence and retribution.

Many developmental theorists locate antisocial behavior as part of a normative developmental pattern that desists over time as adolescents enter adult developmental stages. ${ }^{139}$ Most juvenile offenders stop their patterns of offending, including most who engage in violence during adolescence. ${ }^{140}$ The juvenile court incorporated this perspective on adolescence as a changeable developmental stage in the jurisprudence of the juvenile court, where adolescent offenders were developmentally incomplete. As noted earlier, Judge Julian Mack's classic statement of the original theory of the juvenile court suggested that the function of the court was “... not so much to punish as to reform, not to degrade but to uplift, not to crush but to develop, not to make [the delinquent] an offender but a worthy citizen." 141

Thus, whereas the early juvenile court assumed that some correction was needed to redirect adolescents away from criminality and into pro-social adult behaviors, modern developmental theory suggests that the cessation of delinquency itself is a normative process, regardless of the actions taken by a juvenile court or any other social institution. ${ }^{142}$ Prior research on correctional interventions for juvenile offenders confirms that rates of

138. See Scott \& Grisso, supra note 41 , at 137.

139. See, e.g., Terrie E. Moffitt, Adolescent-limited and Life Course Persistent Antisocial Behavior: A Developmental Taxonomy, 100 Psychol. Rev. 674 (1993); see also Richard Jessor \& Shirley Jessor, Problem Behavior and Psychosocial Development: A Longitudinal Study of Youth (1977); Robert J. Sampson \& John H. Laub, Crime in the Making (1993).

140. Marvin E. Wolfgang et al., Delinguency in a Birth Cohort (1972); Donna M. Hamparian et al., The Violent Few (1978); Marvin E. Wolfgang et al., From Boy to Man, From Delinguency to Crime (1985).

141. Mack, supra note 46, at 107.

142. Some disagreement exists over the precise age trajectories most delinquents take toward desistance, the number of different trajectories, the fraction of active delinquents that persist and for how long, or the social or individual factors that explain differences in patterns of continuity or desistance. See, e.g., Moffitt, supra note 139; Daniel Nagin \& Kenneth C. Land, Life Course Trajectories of Different Types of Offenders, 33 CRIMINOLOGY 111 (1995); John H. Laub \& Robert J. Sampson, Understanding Desistance from Crime, 28 CRIME AND Just. 1 (2001). 
offending decline over time, and the marginal differences in reoffending rates across correctional contexts reflect differences in the strength and integrity of the interventions. ${ }^{143}$

However, there is less agreement on the mechanisms that underlie reductions in the rate of offending during late adolescence, or its cessation by the time most adolescents reach early adulthood. The assumption of adult social roles, with their accompanying increase both in social control and stakes in conformity, provides one explanation for desistance. ${ }^{144}$ Changes in the daily routines of adult life decrease the influence of peers while substituting the informal control of adult social networks. ${ }^{145}$ Psychosocial development, including moral development, improvements in cognitive appraisals, and enhanced reasoning and judgment, are intrapsychic factors that may promote desistance. ${ }^{146}$ These factors include the development of cognitive capacity and competencies including risk perception and preference, social judgment, and temporal dimensions of decision-making. ${ }^{147}$ Attainment of autonomy and independence are benchmarks of adolescent development that reduce motivation for offending once adult social status is reached. ${ }^{148}$ Profes-

143. Ted Palmer, A Profile of Correctional Effectiveness and New Directions for Research (1994); Mark Lipsey, Juvenile Delinquency Treatment: A Meta-analytic Inquiry into the Variability of Effects, in META-ANALYSIS FOR EXPLANATION: A CASEBOOK, 83 (Thomas Cook ed., 1992), Don A. Andrews et al., Does Correctional Treatment Work? A Clinically Relevant and Psychologically Informed Metaanalysis, 28 Criminolocy 369 (1990); Jeffrey Fagan, Treatment and Reintegration of Violent Juvenile Offenders: Experimental Results, 7 JusT. Q. 233 (1990).

144. See Moffitt, supra note 139; Sampson \& Laub, supra note 139.

145. Jeffrey Fagan \& Deanna L. Wilkinson, Guns, Youth and Social Identity, in Youth Violence 373 (Michael Tonry \& Mark H. Moore eds., 1998); Jeffrey Fagan \& Deanna L. Wilkinson, The Social Contexts and Developmental Functions of Adolescent Violence, in Violence in American Schools 71 (Beatrix Hamburg et al. eds., 1998). Violence and other antisocial behaviors often serve a variety of developmental functions associated with peer interactions during adolescence: status and identity, grievance resolution, and avoidance of attacks. Peers are the most critical audience with whom behaviors are learned, scripted, practiced, and refined, while peers confer status and identity by serving as arbiters of social behavior.

146. Richard Jessor et al., Beyond Adolescence: Problem Behavior AND Young Adult Development (1991); Moffitt, supra note 139; John D. Coie \& Kenneth A. Dodge, Aggression and Antisocial Behavior, 3 HANDBOOK OF CHILd PsychOL. (1997); Patrick Tolan \& Nancy Guerra, What Works in Reducing Adolescent Violence? An Empirical Review of the Field (1994) (unpublished manuscript, University of Colorado).

147. For a review, see Scott \& Grisso, supra note 41 , at § II.

148. Fagan \& Wilkinson, supra note 145 , at 71; Laurence Steinberg \& Elizabeth Cauffman, Maturity of Judgment in Adolescence: Psychosocial Factors in Adolescent Decision Making, 20 LAW \& Hum. BeHAv. 249, 253-56 (1996). 
sors Elizabeth Scott and Thomas Grisso conclude that "the fact that delinquent behavior desists for most adolescents as they approach adulthood suggests that criminal conduct . . . is associated with factors peculiar to adolescence."

What is it, then, about adult punishment that disrupts these normative developmental processes and disrupts the natural processes of desistance? Where precisely can we locate the conflict between deterrent and retributive theories on the one hand and theories of adolescent development on the other?

\section{A. Developmental Deficits}

Youths sentenced as adults are incarcerated during critical developmental transitions from adolescence to adulthood. Adolescence is a time of stressful development, marked by changes in both physical appearance and social status. It is a developmental period characterized by physical stress, weak coping skills, tenuous identity and self-image, and high vulnerability to emotional trauma. ${ }^{149}$ It is a prolonged period, beginning with hormonal changes and ending nearly a decade later with the transition to adult social roles, often involving work outside the home.

Adolescence is marked by a series of social transitions, including entry into junior high school and differentiated school tasks, increasing use of the peer group as a critical reference group for exploration of social roles, exploration of opposite-sex relationships, and changing relations with parents and other adults. Adult expectations of teenagers are changing just at the same time that the adolescent's perceptions of himself or herself are undergoing basic changes.

Additionally, this stage of development marks a time of pursuit of some universal goals of adolescence: social affiliation, mastery, social identity, and autonomy. ${ }^{150}$ The daily routines of adolescent development occur primarily within the specific contexts of neighborhood, family, school, and peer group. Apart from family, social interactions occur mainly among groups of similarly situated children within schools or neighborhood peer groups.

Incarceration as an adult skews the social networks and contexts where adolescents experience this phase of development. Most adolescents pass this transitional period in mixed company. Though their social interactions are dominated by peer networks, later adolescence is marked by increasingly frequent con-

149. Beatrix A. Hamburg, Early Adolescence: A Specific and Stressful Stage of the Life Cycle, in Coping ANd Adaptation 101 (G. V. Coelho et al. eds., 1974).

150. Steinberg \& Cauffman, supra note 148. 
tacts with adults. Incarceration as a juvenile is usually of shorter duration, and contact with a diverse population of adults is restored upon release. During longer stays in adult prison, social networks are proscribed and limited to prison inmates of the same age or older, within institutional cliques, and occur for longer periods of time.

The social organization of prison life is a culture organized by older inmates and regulated through violence and exploitation. ${ }^{151}$ The interaction of adolescent developmental status with the rules of this context can reinforce violent behavior, both within the institution and upon release. The social position of adolescents in correctional institutions limits the ways that they can gain social status and social identity that is critical to the developmental period of late adolescence. ${ }^{152}$ Social status inordinately depends on one's position within social hierarchies, and for males those hierarchies are often established through manifestations of physical power or fighting. The continual demand for personal "respect," coupled with limited avenues by which to attain it, sets up conflicts that are often resolved through fighting, a convenient pathway to high status.

Other dimensions of social development may be skewed in adult prison. The quality and availability of services for adolescents in adult institutions compares poorly with the conditions of confinement in juvenile institutions. ${ }^{153}$ The accumulation of developmental deficits during this time disadvantages youths when they re-enter society regarding work, social ties, and marriage. These social roles, including worker, marital partner, neighbor, and family member, are critical to the transition from adolescence to pro-social adulthood. ${ }^{154}$ These conventional social roles serve two functions: they convey status, and they place young adults in contexts of stronger social control that limits their crime opportunities and reduces their motivation for criminality. ${ }^{155}$ The poor quality of material services, including education and vocational training, further limits adolescents' access to these protective social roles.

The developmental contexts of adolescents in contrasting correctional conditions are sufficiently different to produce divergent trajectories of maturation, values, risk assessment and

151. See, e.g., Mark Fleischer, BegGars and Thieves (1995).

152. Jones \& Schmid, supra note 99, at 84-86.

153. See Fagan, supra note 131.

154. SAMPSON \& LAUB, supra note 139, at 160-62, 178.

155. Fagan \& Wilkinson, supra note 145, at 145-46 [article 1]; 79-80 [article 2]; Elijah Anderson, Code of the Streets, The AtLantic Monthly (May, 1994), at 81-94. 
decision-making. ${ }^{156}$ Accordingly, there are two potential developmental consequences of immersion in the disadvantaged context of adult punishment: attenuated development of normative developmental skills and states, and skewed development of skills and states that reflect the contingencies and norms of the adult correctional context. These divergent developmental trajectories reflect the tension between developmental needs and the consequences of retributive policies.

\section{B. Violent Socialization}

Experiences of physical and sexual assault victimization during childhood and early adolescence raise concomitant risks of aggressive and violent behavior in late adolescence and early adulthood. ${ }^{157}$ This is true for both vicarious or indirect victimization $^{158}$ (i.e., witnessing violence), as well as direct experience, or victimization. ${ }^{159}$ Both acute and chronic exposure to violence in childhood and adolescence leads to psychological, physical, and social disruptions. ${ }^{160}$ Acute experiences result in a wider range of reactions and symptoms, but chronic exposure during adolescence imposes particularly weighty developmental and psychological burdens, including post-traumatic stress disorder, distortions in social information processing, and cognitive

156. Steinberg \& Cauffman, supra note 148, at 268.

157. Scott Menard, Short- and Long-Term Consequences of Adolescent Victimization, Youth Violence ReseARCh Bulletin, NCJ-191210. 14 (February 2002) (ucing longitudinal survey data to demonstrate that victimization during adolescence increases the risks during adulthood of committing felony assault and domestic violence, suffering future injuries, engaging in problem durg use, manifesting psychiatric problems including post-traumatic stress disorder, and experiencing marital and job instability. See also, e.g., Albert J. ReIss, JR., \& Jefrerey A. Roth, Understanding and Prevetning Violence (1993).

158. James D. Garbarino et al., Children in Danger: Coping with the CONSEQUeNCES of CoMmunity Violence (1992); Joy Osofsky, The Effects of Exposure to Violence on Young Children, 50 AM. PsYchologist 782 (1995).

159. Cathy Spatz Widom, Does Violence Beget Violence? A Critical Examination of the Literature, 106 PSYCH. BuLL. 106 (1989).

160. See, e.g., Michele R. Cooley-Quille et al., Emotional Impact of Children's Exposure to Community Violence: A Preliminary Study, 34 J. OF THE AM. ACAd. OF Child \& Adolescent Psychiatry 10 (1995), 1362-68.; Fitzpatrick, Kevin M. and Janet P. Boldizar, The Prevalence and Consequences of Exposure to Violence Among African-American Youth, $32 \mathrm{~J}$. of the Am. Acad. of Child \& Adolescent PsychiATRY 2, 424-30 (1993); Robert S. Pynoos et al., Life Threat and Posttraumatic Stress in School-Age Children, 12 Archives of General Psychiatry 1057-63 (1987); Carl C. Bell \& Esther J. Jenkins, Community Violence and Children on Chicago's Southside, 56 Psychiatry: InTerpersonal \& Biological Processes 1, 46-54 (1993); Dante Cicchetti \& Michael Lynch, Toward an Ecological/Transactional Model of Community Violence and Child Maltreatment: Consequences for Children's Development, 56 PsYchiatry: Interpersonal \& Biological Processes 1, 96-118 (1993). 
appraisals of everyday social interactions, and depression and other mental disorders. ${ }^{161}$ These experiences can influence early adult socialization and adaptations of cognitive and affective states, leading to increased rates of violence as adults, as well as both adverse internalizing and externalizing emotional responses.

Various learning theories associated with aggression stress the central role of cognition in the development of violence. Aggressive behavior is maintained over time by cognitions that include hostile attributional biases, aggressive scripts, and normative beliefs that validate aggression. ${ }^{162}$ The increased dosage of violence exposure in adult incarceration, for example, proscribes the number of scripts that are available for learning and adaptation, establishes a normative developmental context for the internalization of violent and antisocial scripts, and provides daily affirmation for the validity of hostile attributional bias in social interactions. ${ }^{163}$

Adolescents incarcerated as adults have greater risk of violence victimization, both directly and vicariously. ${ }^{164}$ This exposure skews both affective (emotional) and cognitive (scripts) dimensions of development. While juvenile institutions are hardly safe havens for adolescents, there is a measurably greater

161. Garbarino et al., supra note 158. Kenneth E. Dodge \& Nicki R. Crick, Social Information Processing Bases of Aggressive Behavior in Children, 16 PERSONALITY \& Soc. PsYchol. Bull. 8 (1990).

162. Rowell J. Huesmann, An Information Processing Model for the Development of Aggression, 14 Aggressive Behav. 13; Kenneth E. Dodge, New Wrinkles in the Person-versus-Situation Debate, 4 PsYchol. INQUIRY 284 (1993).

163. See Fagan \& Wilkinson, supra note 145, at 77-80. (Fagan and Wilkinson \#2). Adolescents employ "scripts" as part of a strategy of "impression management" to gain status and dominance in potentially violent transactions. For example, in street code, displays of toughness are directly related to reputation building, offering a deterrent value necessary to avoid continual attacks from other males seeking to build their own reputations. These are "scripts" of survival in milieus where violence is normative. Scripts are learned and reinforced within specific social contexts, such as street scenes or, equally likely, prison cliques. "Context" is a social setting that serves several purposes: providing a stage where events play out for public consumption, creating expectations of specific behaviors given specific situations, providing a regulatory structure for behaviors (setting social costs and returns), and providing opportunities for specific forms of interaction that may lend themselves to violence or peaceful behavior. The latter might refer to physical spaces such as prisons, or social spaces such as streetcorner groups. The development of scripts, the processes of decision making, and the social definitions of conflict and other functions served by violence, form in such specific social contexts. These contexts shape normative definitions, imperatives or expected behaviors, costs and rewards of violence.

164. See Forst et al., supra note 95, at 9. 
dosage of violence for juveniles incarcerated as adults. Longer sentences for adolescents in adult courts result in chronic rather than acute violence exposure. ${ }^{165}$ And, exposure to violence while incarcerated can compound antecedent violence exposure experiences. Major life events, such as violence victimization as a younger adolescent before incarceration, may be distal events in current social and emotional functioning, but they may exert a powerful proximal impact by aggravating current stress and violence exposure. ${ }^{166}$

Moreover, the absence of social support mechanisms in adult incarceration facilities increases the risk of maladaptive reactions, including aggressive responses that mirror the violence in everyday prison life. ${ }^{167}$ Compared to adolescents in juvenile programs and services, adolescents incarcerated as adults are immersed in inmate cultures of violence, where violence provides tangible returns including status, protection, and material goods or services. ${ }^{168}$ Gangs are a controlling force in prison life, and they trade material goods and human services, in an informal economy regulated by violence. ${ }^{169}$ Affiliation often requires a strategic choice based on both status and safety concerns.

Similar to socialization deficits, immersion of adolescents in adult correctional settings may produce several developmental deficits. One deficit results from the absence of social support mechanisms to mediate the effects of chronic violence exposure. Without both emotional support and contextual mediators, vio-

165. Chronic daily stresses produce a wide array of emotional and physical disorders in adolescents. See Bruce Compas et al., Coping with Stressful Events in Older Children and Younger Adolescents, $56 \mathrm{~J}$. Consulting \& Clinical Psychol. 405 (1988).

166. See Arnold Linsky et Al., Stress, Culture ANd Aggression 169 (1995).

167. Id.; Nan Lin et al., The Buffering Effect of Social Support Subsequent to an Important Life Event, $26 \mathrm{~J}$. HEALTH \& Soc. Behav. 247. Socially generated stress is an important organizing principle for children's exposure to violence primarily because of its broad association with a wide array of adaptive behaviors and mental and physical health disorders. When severe stress is experienced as a life event, such as violence exposure, an individual is motivated to reduce the discrepancy between negatively perceived aspects of the environment and his or her own personal requirements. This goal is achieved either by adapting to the environment or exerting control over it. Whether control or adaptation occurs depends on both the change potential of the physical or social environment (which is quite low for an adolescent in prison), or the individual's own perceived control over environmental events (again, low for adolescents in prison).

168. John Irwin, The Felon (1972); Barry C. Feld, Inmate Subcultures and Delinguency (1977); Mark Fleischer, BegGars and Thieves (1995).

169. See Hans Toch and Kenneth adams, Coping: Maladaptation in Prisons (1989); Anthony E. Bottoms, Interpersonal Violence and Social Order in Prisons, in Prisons 205, 245-49 (Michael Tonry and Joan Petersilia eds., 1999). 
lence exposure produces distortions in cognitive and emotional development that may elevate later aggression. Narrow contexts of choice of behaviors may produce a restricted range of choices in other social contexts following prison release. A second deficit consists of the attenuation of identity formation, the conflation of violence with masculinity and social identity, and the internalization of violence norms. ${ }^{170} \mathrm{~A}$ third is the attenuation of forms of internal behavioral regulation. Although weak regulation of anger and violence may have led to incarceration, these antecedent conditions are internalized and unchecked during prolonged periods of violence exposure and practice in the absence of the influence of other models of control.

\section{Economic Disenfranchisement}

The link between unemployment and crime is mediated for many adolescents by their involvement in the legal system during early adolescence. ${ }^{171}$ Several studies focus specifically on the negative effects of incarceration of adolescents on future employment. ${ }^{172}$ In general, the impact of a criminal conviction during adolescence creates collateral disabilities that have severe and compounding adverse effects on the employment and recidivism outcomes of minority adolescents as they enter adulthood. ${ }^{173}$ In addition to economic disenfranchisement, a felon is disqualified from jury service, ${ }^{174}$ the right to vote, ${ }^{175}$ and the right to hold elective office. ${ }^{176}$ In an increasing number of states, ${ }^{177}$ felons are \#1).

170. Fagan \& Wilkinson, supra note 145 , at 150-52. (Fagan and Wilkinson

171. Mercer Sullivan, Getting Paid (1989); Sampson \& Laub, supra note 139; Jeffrey Fagan \& Richard Freeman, Crime and Work, 25 CRIME \& Just.225, 238-45 (1999).

172. Richard B. Freeman, Crime and the Economic Status of Disadvantaged Young Men, in URBAN LABOR MARKeTS AND Job OPPORTUNITY 215-26 (George E. Peterson \& Wayne Vroman eds., 1992); John Hagan, The Social Embeddedness of Crime and Unemployment, 31 Criminology 465 (1993).

173. See Freeman, supra note 172, at 201; George Fletcher, Disenfranchisement as Punishment: Reflections on the Racial Use of Infamia, 46 UCLA L. REv. 1895, 1897 (1999).

174. See, e.g., Ariz. Rev. Stat. Ann. § 21-201 (West Supp. 1998); Cal. Crv. Proc. Code $\$ 203$ (West 1999); N.Y. Jud. Cr. Acts Law $§ 510$ (McKinney 1999); N.M. Stat. \$ 38-5-1; Tex. Stat. \$ 62-102.

175. See e.g., Fla. Const. Art. VI, § 4; Ariz. Rev. Stat. AnN. \$13-904

176. See e.g., Fla. Const. Art. VI, $\S 4$; Minn. Const. ART. VII, $\S \S 1,6$; N.C. Const. Art. VI, $\$ 8$

177. Marc A. Maurer, Race to Incarcerate 186-87 (1999). Maurer reports data from a study by the Sentencing Project and Human Rights Watch that estimates that nearly one American in fifty is currently or permanently dis- 
disenfranchised for life. ${ }^{178}$ Disenfranchisement disproportionately and severely affects African American males, consistent with their distorted presence in the incarceration population: of the 3.9 million American felons who are disenfranchised, nearly 1.4 were African American males, representing $13 \%$ of all black males. ${ }^{179}$ Not only does disenfranchisement disproportionately affect young African American males, it severely reduces their ability to influence these policies.

The result of legal sanctions during adolescence, especially jail or prison, seems to lead to a de facto exclusion from legal work and heightened prospects for re-offending and re-incarceration. Sampson and Laub claim that, "job stability is central in explaining adult desistance from crime." 180 The effects of unemployment, whether direct or mediated through legal constraints, are strongest for the African American youths and youths from bluecollar backgrounds. ${ }^{181}$

The attachment of a felony conviction record as an adult creates compounding barriers to employment during early adult years. The workplace stigma of a felony conviction record appears to mortgage opportunities and prospects for stable employment in adult life. ${ }^{182}$ This complicates reintegration of offenders returning from program placements or institutional commitments. Adolescents punished as juveniles can avoid reporting a felony record, but adolescents with adult conviction records face employment discrimination in seeking work that compounds other developmental deficits regarding socialization and behavioral development. Accordingly, adult punishment attaches a disadvantage that is cumulative over time. Adolescents punished as adults are likely to have limited access to stable employment and lower wages following incarceration. Moreover, their exclusion from legal work in turn may lead to weak social integration due to truncated contacts with adults in work settings.

enfranchised as a result of a felony conviction. See also Michael A. Fletcher, Voting Rights for Felons Win Support, WAsH. Post, Feb. 22, 1999, at A1.

178. MAUER, supra note 177 , at 186-87.

179. Id.

180. SAMPSON \& LAUB, supra note 139 , at 162.

181. Terence Thornberry \& R.L. Christenson, Unemployment and Criminal Involvement: An Investigation of Reciprocal Causal Structures, 56 AM.Soc. Rev. 609 (1984).

182. Jeffrey Fagan \& Richard B. Freeman, supra note 171, at 227; SAMPson \& LAUB, supra note 139, at 165-68.; Freeman, supra note 172, at 217, 226. 


\section{Summary}

Life course consequences in other domains of adolescent development are also adversely affected by incarceration of adolescents as adults. ${ }^{183}$ In addition to negative impacts on jobs, incarceration as an adolescent leads to lower rates of successful marriage and child rearing. ${ }^{184}$ However, none of the prior research distinguished adult and juvenile correctional placements. These studies were concerned only with incarceration as a juvenile and they did not control for the labeling and stigmatization effects of an adult conviction record.

Accordingly, there are potentially important consequences of treating juveniles as adults that remain unknown, differences that may weigh significantly on the evaluation of legislative activism to harden punishment for adolescents. Differences in the conditions of confinement and the quality of correctional services between juvenile and adult correctional placements predict greater disadvantage in the life course outcomes of adolescent offenders who are processed in the criminal system. There may be differences in the quality of services and programming, with less attention to the development of human capital in preparation for adult roles. There may be differences in the "prisonization" of adolescents based on differential exposure to adult inmate cultures. Or, there may be differences in the rates of victimization and exposure to violence, with adolescents in adult confinement facing higher rates of physical and sexual assault, increasing their risks of subsequent violent behavior. ${ }^{185}$ Finally, the cumulative or interactive effects of these factors may influence developmental outcomes and behaviors following incarceration.

\section{Allocating Harm: Punitive Necessity and Public Policy}

Sorting through the noisy debates on judicial forum for adolescent offenders, two messages are consistently louder than others. First, legislators claim that adolescents who commit serious crimes are as culpable for their crimes as any adult. ${ }^{186}$ In other words, when a person reaches a certain threshold of crime severity at a particular age, there is no culpability discount that attaches to age. Of course, the variation from state to state sug-

183. For a summary, see Richard E. Redding, Juvenile Offenders in Criminal Court and Adult Prison: Legal, Psychological and Behavioral Outcomes, Juv. \& FaM. CT. J. 1 (1999).

184. See Sampson \& Laub, supra note 139.

185. See Forst et al., supra note 95, at 9.

186. See Scott \& Grisso, supra note 41 at 148-49. 
gests that the basis for this claim is grounded in neither theory nor research. The claim is challenged, moreover, by empirical research on adolescent development, and its ill fit with common law traditions of diminished culpability or "incapacity."

The second, corollary message is that these adolescents have committed acts of sufficient harm that merit more severe punishment than adolescents who have committed less serious crimes. ${ }^{187}$ In this view, a doctrine of retributive justice justifies expulsion from the juvenile court, and attaches liability for more "disfiguring" forms of adult punishment. Accordingly, adolescents expelled from the juvenile court have either committed more harmful acts that merit punishment beyond the capacity of the juvenile justice system, or they are judged unlikely to desist from these acts, requiring sanctions unavailable in the juvenile justice system.

However, the lessons of three different studies involving three different mechanisms for expulsion from the juvenile court suggest that there are sharp costs to retributive justice that may neutralize if not outweigh the retributive returns. Yes, tangible punishments differ for adolescents in the juvenile and adult courts, and yes, they are disfiguring. But the deterrent power of harsher sanctions tends to decline the more often and more heavily it is imposed. ${ }^{188}$ The reason, it appears, is the clash of retributive principles with theories of adolescent development and developmental criminology. And the overreach of new transfer law and policy burdens the criminal courts with children whose risks simply do not rise to a level that would merit such harsher punishment. The fact that exposure to adult punishment is a form of toxic exposure confirms the danger of these new mechanisms.

The shift in discretion from judges to legislatures and prosecutors also raises constitutional issues. Several state appellate cases have upheld this transfer of discretion. But the concentration of discretion at the charging stage is problematic when the

187. Others suggest that while two youths may commit equally serious crimes, one may be more changeable-that is, amenable to treatment-than is the other. See Christopher Slogobin, Treating Kids Right: Deconstructing and Reconstructing the Amenability to Treatment Concept, $10 \mathrm{~J}$. ConTEMP. Legal. Issues 299 (1999). However, the application of amenability principles is asymetrical. These principles may inform waiver decisions at lower thresholds of crime severity, but are irrelevant at higher levels of crime severity. In the latter case, the demands of penal proportionality and retributive justice trump any other considerations. See ZimRING, supra note 4, at 162.

188. See Daniel Nagin, supra note 106 (describing sanction saturation effects that diminish the deterrent effects of criminal punishments when they are widely and non-contingently applied). 
charging decision is conflated with the determination of court jurisdiction, and its gravity is amplified when the consequences of jurisdictional transfer are considered. This conflict of interest also raises questions regarding the separation of powers and judicial independence. ${ }^{189}$

By eliminating discretion on transfer, or conflating discretion with other enforcement functions, the new transfer policies cut surgically into juvenile court populations, relocating broad heterogeneous categories of adolescent offenders to harsher and disfiguring punishments in the adult courts. Recent studies suggest that the few worthy targets of these policies are well outnumbered by many others whose culpability and risk are inflated by rhetorical excess on youth crime.

189. See Feld, supra note 49. 